\title{
An Interfaith Perspective on Globalization for the Common Good
}

The third Annual International Conference on Globalization for the Common Good was held on 27-31 March 2004 at the Bustan Rotana hotel, 
Dubai, the United Arab Emirates. More than thirty participants, representing academics, peace activists, theologians, environmentalists, and businessmen from the United States, Europe, Japan, the Gulf region, Australia, and South Africa attended the eleven plenary sessions. These were divided under the following headings: Muslim-Christian Dialogue for the Common Good; Religions and Social Justice; Profit and the Common Good: Conflict or Convergence?; Religions and the Common Good; Urbanization and Cities in a Global Age; Globalization and Civilizations; Ethical Perspectives on Globalization; Interfaith Dialogue and Peace-building; Natural Resources, Ecology and Development; Youth in a Global Age; and Science and Technology in a Global Age. The conference was officially opened by the founder and chief convenor of the Interfaith Perspective on Globalization for the Common Good, Dr Kamran Mofid of the United Kingdom.

Dr William Lesher (Lutheran School of Theology, Chicago) in his "Pathways to Peace" identified the major factors supporting globalization and showed how global trends become indigenized through the process of glocalization. Sister Beatrice Mariotti's (St. Mary's Catholic High School, Dubai) "Globalization and Christian-Muslim Spiritual Dialogue in Dubai" dealt with three challenges to cultural identity: consumerism, the Internet, and isolationism. Markus Glatz-Schmallegger (Catholic Social Academy of Austria) argued in his "Religions Acting for "Bridging and Linking Social Capital' in the Context of Globalization," that religion, as an organ of civil society, can contribute significantly to social capital.

In the session on "Profit and the Common Good: Conflict or Convergence?" Kamran Mofid outlined both the negative and positive aspects of globalization. This was followed by a lively discussion on how globalization's benefits could be extended to all and not confined to a minority of individuals, multinationals, and states. Suleman Dangor (University of Kwazulu-Natal, South Africa) outlined the positive and negative features of globalization, and then elaborated on the role that religions could play in ensuring that its benefits are spread equitably while developing nations are protected from its negative impact.

Jakob von Uexkull (The Right Livelihood Awards, London, UK), in his "Global Values and Global Stability," made a case for equitable access to the world's natural resources. The possibility of this happening is greater now that we are moving to a post-secular world. Keyvan Tabari emphasized the importance of national sovereignty. Since the demise of the USSR 
as a global power, the US has attempted to "manage" the world through the injection of capital, provision of services and recruitment of labor.

However, there are serious disagreements between the US and other nations over the following issues: conservation of the environment, conditions of assistance from the World Bank and the IMF, definition of international crimes, modality of dispute resolution, rules of warfare, human rights, and reformation of existing domestic legal systems.

Annick de Witt (University of Nijmegan, The Netherlands), Peter Milward SJ (Renaissance Institute, Sofia University, Japan), and Audrey Kitagawa (Advisor: Office of the Special Representative of the Secretary General for Children and Armed Conflict, United Nations) spoke on environmental issues. George Katodrytis (American University of Sharjah) and Wayne Green (Global Affairs, United Kingdom) discussed the issue of urbanization in a Global Age. Tara Stuart (Keene State College, USA) and Jeffery Smith (Forum on Geonomics, USA) gave an ethical perspective on globalization.

Bhai Sahib Mohinder Singh (Guru Nanak Nishkam Sewak Jatha, Birmingham, UK), Michael Bos (Al-Amana Centre, Oman), Judith Jensen (Oregon Institute of Technology, USA), Athar Murtuza (Seton Hall University, USA), Jim Kenney (Interreligious Engagement Project, USA), Alan Race (St Andrews Church, Leicester, UK), Toh Swee-Hin (Griffith University, Australia), Jane Samuels (Cultural Development Consultant, UK), Lawrence Woods (American University of Sharjah), and Hazar Ibdah (American University of Sharjah) focused on interfaith issues. Josef Boehle (University of Birmingham, UK), David Coleman (Chaminade University of Honolulu, Hawaii), and Kathleen Kevany (United Nations University, Japan) proposed ways in which religion could contribute to the common good.

Najdia Diane Hamden (Leadership Programs, USA) and Agnetta Borgman (Research Social Worker, Dubai) spoke on youth and women in a global age, respectively. Christopher Houghton Budd (Centre for Associative Economics, Canterbury, UK) deliberated on business ethics, and Raymond Hamden (Comprehensive Medical Centre, Dubai) focused on science in a global age.

One major criticism that could be leveled at the conference is that many participants did not relate their papers to the topic, but rather confined them to interfaith relations. Furthermore, several major aspects of globalization were not dealt with in any of the presentations. Nonetheless, the conference provided a platform for an exchange of ideas as well as for networking. 
Hopefully, the next conference in Kenya, whose leitmotif is the Quest for Justice and Peace, will focus more substantially on globalization's impact on Africa.

Suleman Dangor

School of Religion and Culture

University of Kwazulu-Natal

Durban, South Africa 